技術のニューウェープ

\title{
環境対応型のプラスチック 食品容器について
}

瓶のリサイクル, 使い捨て容器の処理問題等, 環境保全対策は, 今や醸造業界でも第一義的に捉えなければな らない時期にきた。このような流れの中で環境対応型プラスチック容器の開発, 実用化への取り組みが真剣に考 えられている。その技術的な背景と現状を解説していただいた。

\section{久 保 直 紀}

\section{1. は じめに}

オゾン層の破壊, $\mathrm{CO}_{2}$ 等による大気污染の進行, 酸性 雨, 森林資源の枯渴など地球規模で深刻化する環境污染 に対して, 世界的な環境保全対策が進められている。こ うした中で，私たちの日常生活に深くかかわっているプ ラスチック包装材料, 特に食品向けのプラスチック容器 と環境とのかかわりにも関心が高まり, 環境対応型のプ ラスチック食品容器の開発, 実用化への取り組みが進ん でいる。本稿では, 生分解性プラスチックや処理の段階 で環境への負荷の少ない易処理型プラスチックなど環境 対応型のプラスチック食品容器・素材の開発と実用化の 状況を紹介する。

\section{2. 生分解性プラスチック}

プラスチックをはじめとする多くの合成高分子は，天 然素材にはない多くの優れた機能を持つ素材として普及 している。プラスチックに代表される合成高分子は，そ の優れた化学的, 物理的な機能や特性によって, 日常生 活や様々な産業分野での利便性を飛躍的に向上させてき た。しかし，使い捨て型と言える現代の多消費型の社会 にあっては「様々な環境条件下でも物性が安定で腐らな いといらプラスチックの特性に変わって，使用時には 従来のプラスチックと同様の機能や特性を備え, 使用後 には自然環境に負荷を与えず，土壤中や海水中の微生物 によって分解するといら新しいタイプの素材・生分解性 プラスチックヘの期待が高まっており, 現在, 農業フィ ルムや土木用シートなどの農業・土木資材分野, 漁網な
ぞの水産資材分野，医療用分野，さらにトレーなどの食 品容器分野で, 生分解性プラスチックの開発や実用化へ の取り組みが進んでいる。

\section{2-1. 生分解性プラスチック開発の動向}

生分解性プラスチックの開発は, すでに十年以上前か ら世界各国で試みられている。特に, 最近のバイオテク ノロジーの急速な発達や高度な合成化学技術の進歩など によって, 生分解性プラスチックの実用化は現実的なも のになってきた。

数年前から, 米国やカナダでは米国化学会 (ACS), 米 国材料技術規格協会 (ASTM), 北大西洋条約機構 (NA TO）などの機関が生分解性プラスチックに関する 国際 会議を相次いで開催し，様々な研究成果が報告された。 日本でも, 通産省の主導で設立された生分解性プラスチ ック研究会（会長・岸本泰延昭和電工会長）の主催によ る第一回生分解性プラスチック国際会議が昨年の 10 月 に東京で開かれ，世界各国からこの分野の研究者が一堂 に会した。また,このシンポジウムでは, 現在象用化ま たは研究中の生分解性プラスチックのサンプルが約 29 種類が展示された（第 1 表）。

このように生分解性プラスチックの研究は, 我が国で も活発化している。

こらした中で, 昨年 7 月に通産省の主導で設立された 「地球環境産業技術研究機構」が, $\mathrm{CO}_{2}$ 固定化, 代替フ ロンガス, 高機能バイオリアクターと共に, 生分解性プ ラスチックの開発プロジェクトをスタートさせた。この プロジェクトは, 工業技術院微生物工業技術研究所等と の共同研究で実施しているもので, 平成 2 年度から 8 年

The Trend of the Development of Environment-Minded Plastic Packages

Naoki Kubo (Chuo Kagaku Co., Ltd.) 
第 1 表 国際シンポジゥム/サンプル展示品一覧

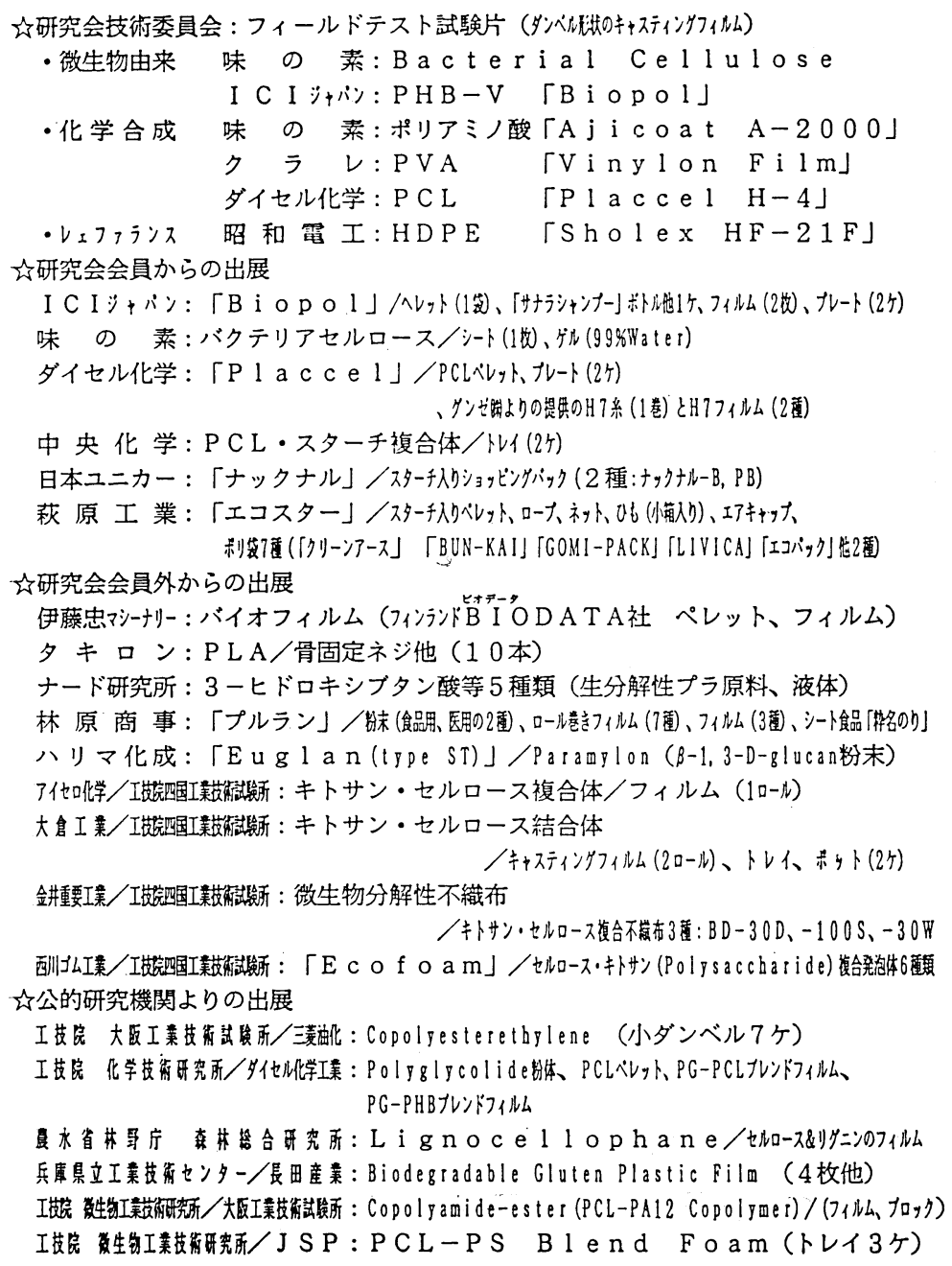

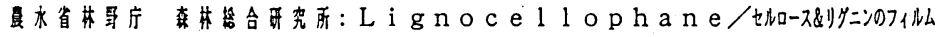

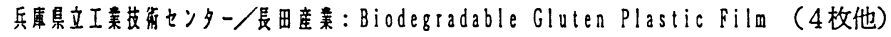

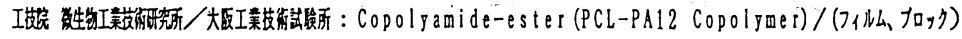

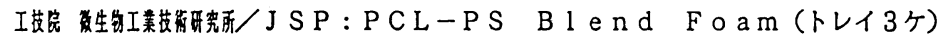

間の予定で実施される。初年度の予算は 1 億 8 千万円で ある。このプロジェクトでは, 開発すべき生分解性プラ スチックを《微生物由来タイプ》, 《バイオマス由来タイ プ》, 《新規化学合成タイプ》の3タイプとしており, そ れぞれのテーマ毎に研究が始まっている。これらのタイ プの生分解性プラスチックの開発の国内外の現状は第 2 表のとおりである。

\section{《微生物由来タイプ》}

微生物由来タイプでは, 英国の ICI が昨年 5 月から本 格的な市場開拓を開始した PHB（ポリ・ベータ・ヒド ロキシ酪酸) 系ポリマー（商品名バイオポール）が代表 的な素材と言える。ICI のバイオポールは，アルカリゲ ネス・ニートロファス（水素細菌）と呼ばれる微生物に 炭素源としてグルコースとプロピオン酸を与えると体内
で PHB 等のポリエステルを合成するという水素細菌の 性質を利用して，工業的に生産したもの。バイオポール は, 西独のウェラ化粧品が昨年 5 月から発売したシャン プーボトルに採用されて扮り, 今後化粧品容器の分野等 でこの材料が使われていく可能性が高まっている。

PHB 系ポリェステルに関する研究では，米国・MIT （マサチューセッツ工科大学）のシンスキー教授, カナ ダ・マックギル大学のマチェソー教授, 東京工業大学の 土肥義治助教授の研究などが知られており世界的に注目 されている。

なかでも土肥助教授の研究は, 水素細菌に与える炭素 源の種類や組み合わせ比率を変化させることによって体 内で合成されるポリエスデルの種類をコントロールし， PHB・ホモポリマーから PHB・HV・コポリマーや $4 \mathrm{HV}$ 
第 2 表 生分解性プラスチックの研究の比較

\begin{tabular}{|c|c|c|c|c|c|}
\hline & 状 & 特 & 用 & 間 題 点 & 開発課題 \\
\hline $\begin{array}{c}\text { 1. 微生物に } \\
\text { よる生産 }\end{array}$ & 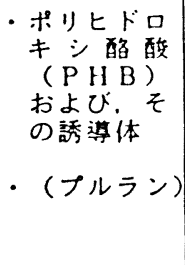 & 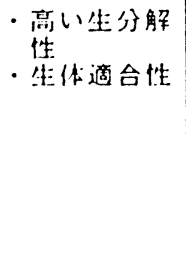 & 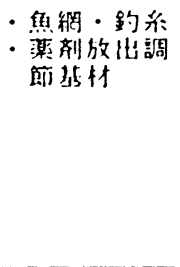 & 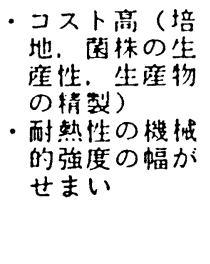 & 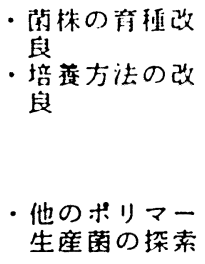 \\
\hline 2. ハハイオマ & 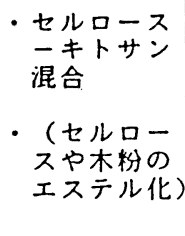 & $\begin{array}{l}\text { ・高い生分解 } \\
\text { 性 } \\
\text { •通気性がお } \\
\text { る }\end{array}$ & $\begin{array}{l}\text { ・宸業用フィ } \\
\text { ルム } \\
\text { ・鉢ひひも }\end{array}$ & $\begin{array}{l}\text { ・熟可盟性がな } \\
\text { ・永に弱い } \\
\text { - 資愿の制約 }\end{array}$ & $\begin{array}{l}\text { ・加エ方法の開 } \\
\text { 発 } \\
\text { - 耐水性の付与 } \\
\text { ・デンプン，ア } \\
\text { ルギン酸等. } \\
\text { 他のバイオ } \\
\text { スの利用 }\end{array}$ \\
\hline $\begin{array}{l}\text { 3. 生分解性 } \\
\text { の合成高分 } \\
\text { 子の開発 }\end{array}$ & 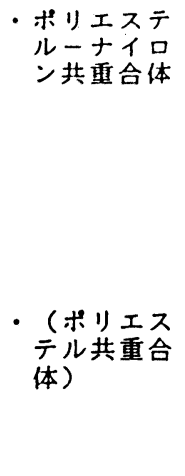 & 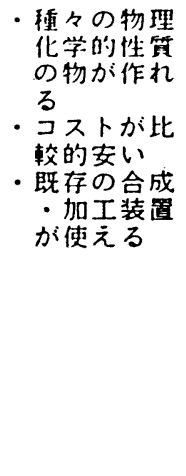 & 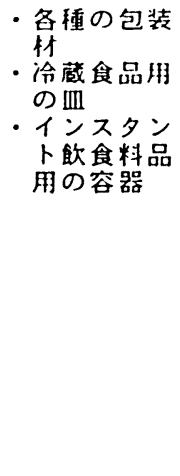 & $\begin{array}{l}\text { ・完全分解性に } \\
\text { するた热 } \\
\text { 重合体反応の } \\
\text { 制午が必要 }\end{array}$ & 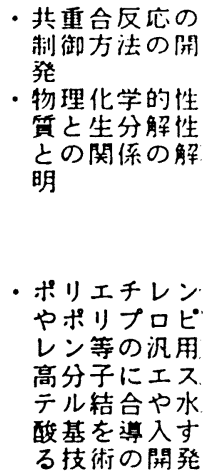 \\
\hline
\end{tabular}
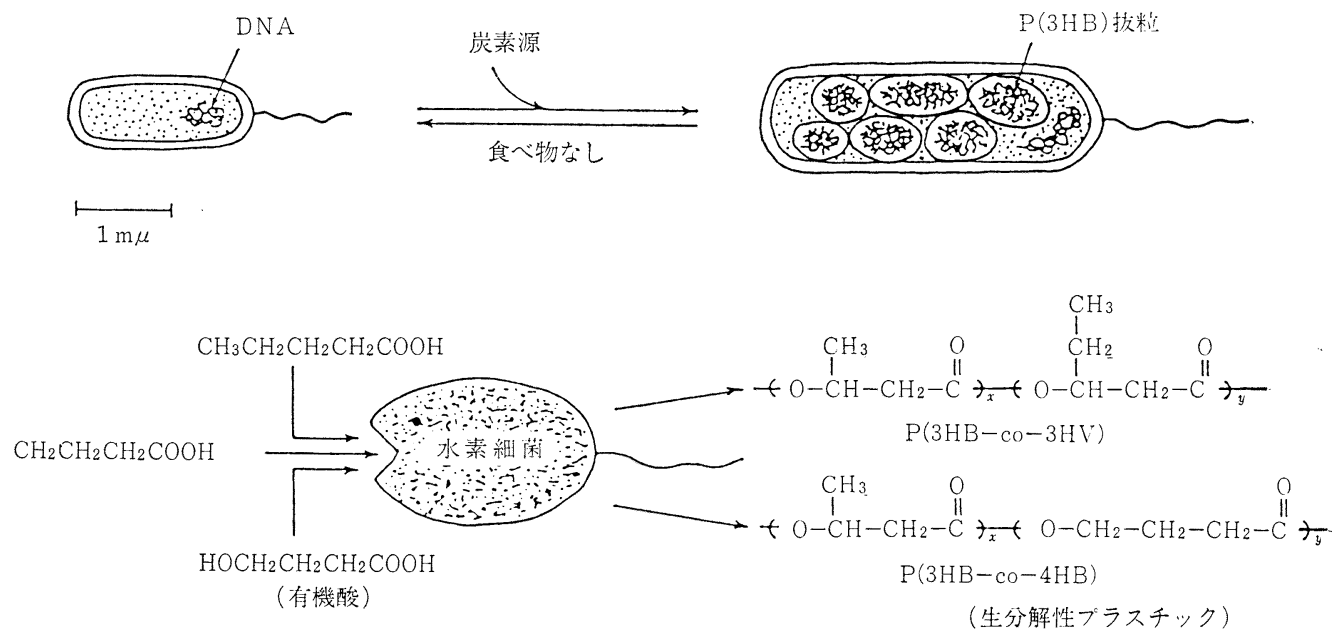

第1図 微生物によるプラスチックの生産（例）

コポリマーなど幅広いタイプの PHB 系コポリマーを得 られるといらもの。生産されるポリマーの性質も, プラ スチックに近い性状からゴム性状のものまで自由に得ら
れ，実用性の高い生分解性バイオポリマーとして注目さ れている(第 1 図)。

このほか我が国では, 三菱化成, 大成建設, 西部ガス, 
住友金属工業などが, PHB の研究に取り組んでいると 見られている。

また，地球環境産業技術研究機構のプロジェクトに参 加して, 微生物由来タイプの生分解性プラスチックの研 究に取り組んでいる企業は, 大成建設, 電気化学, 鐘淵 化学, 東洋紡, 積水化学の 5 社である。

《ハイオマス由来タイプ》

バイオマス由来タイプの分野では, 天然界に存在する 多糖類やセルロースなどを利用した様々なポリマーが研 究されており, 生分解性プラスチックのひとつとして期 待されている。

これまでのハイイオスタイプの生分解性プラスチック の代表的な研究としては, 西独のバッテル研究所のグリ ンピース中のアミロースを利用した生分解性プラスチッ クや、我が国の四国工業技術研究所が研究したセルロー スとキトサンを利用した多糖類系ポリマー等が知られて いる。

バッテル研究所の開発した生分解性プラスチックは, 成分の $90 \%$ がアミロース成分で, すでに半透明なフィ ルムが試作されている。バッテル研究所によれば, これ は熱可塑性生分解性プラスチックであり, 包装用等の分 野で需要が期待されている。

また四国工業試験所の生分解性プラスチックは, 西川 ゴム, アイセロ化学, 金井重要工業など数社に製造技術 がライセンスされ, 不織布, フィルム, 発泡体などの製 品の実用化研究が進められている。

地球環境産業技術研究機構のプロジェクトで, バイオ マスタイプの生分解性プラスチックの研究に取り組んで いるのは, 中央化学と日澱化学の 2 社である。

《新規化学合成タイプ》

新規化学合成タイプでは, 工業技術院微生物工業技術 研究所の常盤豊主任研究官の研究した脂肪族ポリエステ ル系コポリマーが知られている。これは, 脂肪族ポリエ ステルと沉用プラスチックとのコポリマーで, 脂肪族ポ リエステルには PCL (ポリカプロラクトン)を利用して いる。これまで PA（ポリアミド）やPET (ポリエチレ ンテレフタレート) など芳香族ポリエステルとの共重合 体があり, 新規合成技術による量産化可能な生分解性プ ラスチックとして注目されている。

さらに工業技術院化学技術研究所が, ダイセル化学と の共同研究によって開発した一酸化炭素を用いた新しい 生分解性プラスチックも注目されている。

また新規化学合成によるタイプの関連素材として, 脂 肪族ポリエステルの PCL と天然素材である有機物や無 機物をフィラーとして利用した独自の生分解性プラスチ ックの研究も活発化している。

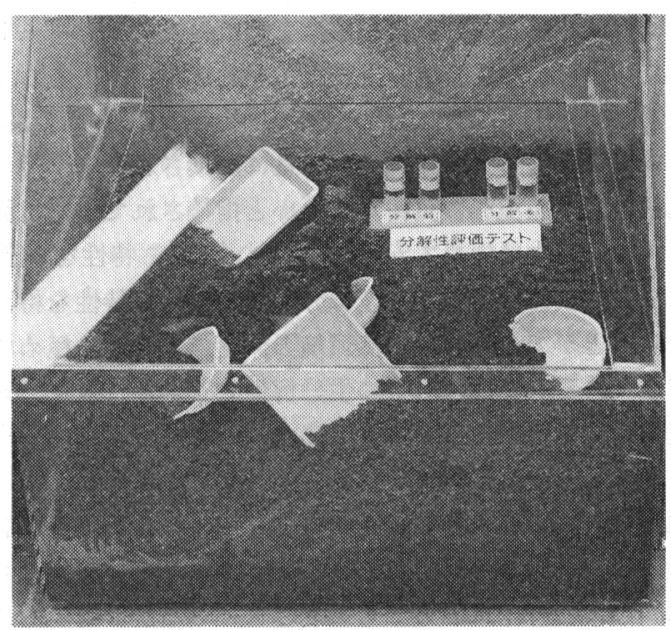

写真 1 微生物工業試験と中央化学が共同開発した 生分解性プラスチックのサンプル

特に知られているのが, 工業技術院微生物工業技術研 究所の常盤主任研究官と中央化学が開発した, PCL と 多量の澱粉を高配合で複合化させたタイプや，炭酸カル シウム等の無機物と PCL を高配合で複合化した生分解 性プラスチックがある。これらの新素材は, 加工性や物 理的特性が比較的汎用樹脂に近ついて拈り, 実用性を有 し，コスト競争力を持った生分解性プラスチックとして 期待されており, 実用化研究が進められている（写真 1 )。

なお, 地球環境産業技術研究機構のプロジェクトで新 規合成技術をテーマに取り組んでいる企業は、ダイセル 化学と JSP の 2 社である。

\section{2-2. 定義と評価方法の開発について}

生分解性プラスチックの開発と平行して, 定義の確立 と評価方法の研究も進められている。この研究分野で は, 米国の ASTM が国際的な規模でのワークショップ

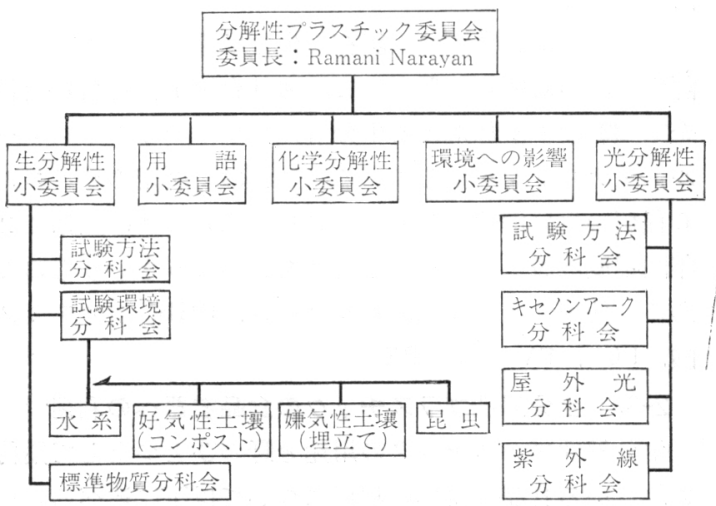

第 2 図ASTM 分解性プラスチック委員会の組織図 
を開催し，専門の委員会を組織して世界の研究をリード している。一般に合成高分子は化学的に不活性であり, 通常の条件下では大気, 水, 光, 生物等の作用を受けに くい性質をもっているため, 大量に廃棄されると, その 処理の面で環境への負荷が大きいと指摘されている。従 って, 使用中は極めて安定で多くの機能や特性を発揮 し，使用後は環境中で安全に分解するといら特性を持た せることができれば, 自然環境の保護のらえから極めて 有用である。問題は, その生分解性や安全性に対する適 正な評価方法である(第 2 図)。

これまで我が国では，合成高分子の評価については， 化学物質の審査及び製造等に関する法律（化審法）に試 験方法や評価基準が規定されている。これには「分解性」 についての評価試験方法も規定されているが, 基本的に 「現在の合成高分子物質の大半が，自然の環境条件下で 極めて安定した構造を持ち，分解しない。」との考え方 の下にまとめられている。しかし，生分解性プラスチッ クはこうした化審法の考え方に沿った素材とは全く異な る新しい素材であり，その分解性や安全性を確認する上 でも，定義と評価方法の確立が重要である。

こうした背景から通産省では, 平成 2 年度から「生分 解性プラスチックの評価方法の研究」にも乗り出してい る。このプロジェクトには, 化学品検査協会とクラレ, 三菱油化, 日本製鋼所の 4 社が参加している。初年度は 5 千 3 百万円の予算が計上されている。

また, 生分解性プラスチック研究会でも, 通産省のプ ロジェクトの関連研究として定義と評価方法の研究に取 り組んでおり, 生分解性プラスチックのイメージを《少 なくとも分解の一過程において, 生物の代謝が関与して 低分子量化合物に変換することを特徴とする高分子化合 物およびその配合物》とし, 光分解, 酸化分解, 加水分 解等との関連や分解速度, 分解生成物の安全性と自然環 境下で使用した場合の二次公害等との関連についても検 討している。

さらに同研究会では, 現在, 生分解性プラスチックの 評価方法の研究の一環として, 海外企業 1 社を含む会員 企業 22 社の参加による生分解性プラスチックのフィー ルド・テストを実施している。これは, 所定のサイズの 6 種類の生分解性プラスチックを, 水系执よび土系で 2 年間程度埋設して, その分解度を調べようというもので ある。使用サンプルは, 七ルロース, $\mathrm{PHB}$, ポリアミノ 酸, PCL, PVA, HDPE。

\section{2-3. 生分解性プラスチックの食品容器への利用}

生分解性プラスチックの用途分野のひとつとして期待 されている食品容器への利用について以下に述べる。

現在開発途上にある生分解性プラスチックは, その分
解性については様々な評価方法によって, その性質が確 認されているが, 実用化, 商品化といら点では, その用 途によってはまだまだ難しい分野も少なくない。

例えば, 西独のウェラ化粧品がバイオポールによるシ ヤンプー容器を実用化したが, これはプラスチックボト ルに要求される物理的な性質や成型加工の技術にある程 度の見通しがついたためと想像されている。しかし，現 段階での $\mathrm{PHB}$ ポリマーの製造コストから推測して、コ スト的にはかなり高価なボトルであろらことは容易に想 像される。つまり, 現段階ではボトルなど使い捨て容器 分野では，コストに問題があると考えられている。ちな みに, ICI 社によればバイオポールの価格は $\mathrm{kg}$ 当たり 7 千円〜 4 千円としており, 汎用プラスチックの 20〜35 倍に相当している。ただし，将来年間生産量が 1 万 $\mathrm{t}$ を 超えれば $\mathrm{kg} 1$ 千円以下になる可能性もあると見られて いる。

このように, 生分解性プラスチックは, コストをはじ め量産技術, 物理的性質, 加工技術, 分解性の制御等の 多くの課題を抱えており，実用化は，まさにこうした課 題の解決と同時進行であると推測される。

コストの問題については, 微生物工業技術研究所と当 社 (中央化学) が共同研究した PCL と有機物の澱粉ま たは無機物のフィラー等との複合体が最も優位なポジシ ョンにあると言えそうだ。現在の見通しでは, 量産化段 階で, 現在の PCL の価格（kg 当たり 2,500 円）の 10 分の 1 程度に引き下げられる可能性がある。

この PCL 複合タイプの生分解性プラスチックは, コ スト競争力があるらえ, 加工性や物理的性質が PE 等の 汎用プラスチックに近く，原料である PCL は量産化が 比較的容易であるら光, フィラーである澱粉や無機物も。 安価に取得できるなどの特徵がある。

しかし, 生分解性プラスチックを食品容器として実用 化するには, 製品の物理的な特性やコストの問題をクリ アする必要があるが, 何と言っても食品容器としての安 全性を確認することが最も重要であり,さらには分解性 の制御も重要な課題となる。

この点について, 現在研究途上にあるため詳細な内容 の紹介は差し控えるが，世界的に廃プラスチック処理が 問題化しており，その廃プラスチック中に占める食品容 器のウェートが少なくないことから, 廃プラスチック処 理問題の解決の一環として，数年後の実用化を目指し て, 当社では生分解性プラスチックの実用化への積極的 な研究を進めていきたい。

\section{3. 易処理性プラスチック容器}

環境への負荷の少ないプラスチック容器として注目さ

醸 協 (1991) 
れているものには, 燃焼時の発熱カロリーの少ない易焼 却性プラスチックがあげられるが，本稿では当社が商品 化している $\mathrm{CT} \cdot \mathrm{CTF}$ と A-PET について, 以下に簡 単に紹介する。

\section{3-1. CT および CTF について}

$\mathrm{CT} \cdot \mathrm{CTF}$ とは, 当社が開発した熱可塑性樹脂と各種 フィラーとの高配合混合分散技術（樹脂とフィラーとの 複合化技術）をキーテクノロジーとする広範囲な技術で 構成される《CT 技術》を用いて生産されるコンパウン ドとその加工技術によって商品化された製品でこの CT 技術はすでに世界 25 力国で製法特許を取得してい る。

この CT 技術は(1)あらゆる熱可塑性樹脂に非常に広 範囲な種類のフィラーを，最高で $90 \%$ まで均一に配合 できる。(2)マトリックスの樹脂とフィラーとの組み合わ せによって，耐熱特性や強度特性，加工適性など様々な 特性を付与でき，さらにファインセラミックスとの複合 化もできる。(3)世界で初めての発泡剂を使わない画期的 な発泡プラスチックが得られる画期的な新技術が含まれ ている。(4)非食品容器の素材としても充分に実用化でき る,などの特長がある。現在実用化している CT・CTF

\section{第3 表 CT.CTF 物性一覧}

\section{一燃焼特性表}

\begin{tabular}{|c|c|c|c|c|c|c|c|}
\hline 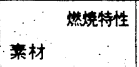 & $\begin{array}{c}\text { 着火温度 } \\
{ }^{\circ} \mathrm{C}\end{array}$ & $\begin{array}{c}\text { 発火温度 } \\
{ }^{\circ} \mathrm{C}\end{array}$ & $\begin{array}{l}\text { 発熱量 } \\
\mathrm{KCal} / \mathrm{kg}\end{array}$ & $\begin{array}{l}\text { 理垥空友 } \\
\mathrm{Nm} / \mathrm{kg}\end{array}$ & \begin{tabular}{|l|} 
煤煙率 \\
$\mathrm{mg} / \mathrm{g}$
\end{tabular} & $\begin{array}{l}\text { 䗳元垂れ } \\
\text { 回/分 }\end{array}$ & $\begin{array}{l}\text { 妷焼速序 } \\
\mathrm{cm} / \text { 分 }\end{array}$ \\
\hline$C T \cdot C T F$ & 340 & 390 & 5300 & 6.7 & 2 & 17 & 21 \\
\hline ポリスチレン & 360 & 500 & 9900 & 10.5 & 40 & 激しい & 20以上 \\
\hline ポリ塩化ビニル & $\begin{array}{c}390 \\
\text { (無可塑) }\end{array}$ & 455 & 4400 & 4.3 & - & - & 自消性 \\
\hline ポリプロピレン & 345 & 390 & 11100 & 11.6 & 5 & 激しい & 24 \\
\hline ポリエチレン & 340 & 350 & 11100 & 11.5 & 5 & 激しい & - \\
\hline 材 & 290 & 295 & 4400 & 3.9 & 1.5 & - & - \\
\hline 紙（新聞 紙） & 230 & 230 & 4400 & - & - & - & - \\
\hline 都 市ゴミ & - & - & 2000 & $1.8-3.0$ & - & - & - \\
\hline
\end{tabular}

○燃焼生成ガス比較表(試料100gより)

\begin{tabular}{|c|c|c|c|c|c|}
\hline 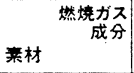 & $\begin{array}{c}\text { 炭酸ガス } \\
\mathrm{g}\end{array}$ & $\begin{array}{c}\text { 一酸化崖素 } \\
\mathrm{g}\end{array}$ & $\begin{array}{c}\text { エタン、メタン } \\
\mathrm{g}\end{array}$ & $\begin{array}{c}\text { スチレン } \\
\mathrm{g}\end{array}$ & $\begin{array}{c}\text { 塩化水絜 } \\
\mathrm{g}\end{array}$ \\
\hline$C T \cdot C T F$ & 170 & 2 & 6 & 0 & 0 \\
\hline ポリスチレン & 315 & 5 & 2 & 35 & 0 \\
\hline ポリ塩化ヒニル & 66 & 18 & 1 & 0 & 29 \\
\hline ポリプロピレン & 285 & 5 & 10 & 0 & 0 \\
\hline 木 材 & 241 & 15 & 0 & 0 & 0 \\
\hline 紙 & 175 & 7 & 0 & 0 & 0 \\
\hline
\end{tabular}

は, ベースポリマーがPP 樹脂で，これに無機物フィラ 一としてタルクを用い, 1 対 1 の比率で複合化したもの (第 3 表)。

$\mathrm{CT} \cdot \mathrm{CTF}$ 容器の特長は, (1) 耐熱温度が $140^{\circ} \mathrm{C}$, 耐寒 温度がマイナス $30^{\circ} \mathrm{C}$ と優れた温度特性を備えており， 電子レンジ容器に最適である。(2)天然のフィラーと混合 することで, 焼却時の発熱量を $\mathrm{kg}$ 当たり 5,300 キロカ ロリーに押えているので, 紙や木と同じょうに処理でき る。また焼却時の発熱が緩やかなために, 廃棄物として 燒却処理する場合焼却炉への負荷が極めて少ない。(3)耐 油性に優れているので, 揚げ物や油ものなどの容器とし ても最適である。(4)厚生省告示 20 号やポリオレフィン 等衛生協議会の自主基準に適合し, 食品容器として安全 である、などである。

CT 容器は, 上記の特性を有する非発泡タイプの食品 容器で, 市場に出回って以来すでに 3 年を経過し, 順調 に市場が拡大しており，スーパーやコンビニエンススト アでのレンジ食品やテイクアウト用の調理ずみ食品容器 として幅広く利用されている。

一方 CTF 容器は, 発泡ガスや発泡剂を全く使用しな い世界で初めての画期的な発泡プラスチック製造技術に よって商品化された環境にクリーンで優れた耐熱特性を 有する発泡プラスチック容器である。

CTF 容器は, 易焼却性と発泡剤を全く使用しない環 境にクリーンなプラスチック容器として, 昨年 6 月に市 場に出回って以来, 爆発的な伸びを見せており，灘神戸 生協での全面採用をはじめ各地の生協やスーパー, ニン ビニエンスストアでの採用が急テンポで進んでいる。

CTF の製法は, CT 技術の一環である発泡ガスや発泡 剂を使用せずに幅広い発泡プラスチック製品が得られる といらものである。現在の技術では, 発泡ポリウレタン や発泡ポリスチレン（発泡スチロール）などの発泡プラ スチックを製造する場合, フロンガス等の発泡ガスや発 泡剂を必要としている（当社ではフロン発泡製品は全く 使用していない）が，地球環境の保全の立場からは，発 泡ガスを全く使用しないことが，最も効果的な環境対策 であり，CTF はこうした地球環境保全に積極的に応え るプラスチック容器である。

CTF の特長は(1)クリーンな発泡プラスチック容器で ある。(2) CT 容器と同様に, $140^{\circ} \mathrm{C}$ といら優れた耐熱性 や焼却適性を持っている。(3)多層化によるプリントタイ プの容器もある。(4)食品容器としての安全性も確認され ている (PL 規格適合品), などである。

当社では, CT・CTF を富沢工場で生産しているが, 需要が急拡大しているために, 富沢工場の設備の本格的 な増強を進めているほか，その他の工場でも CT・CTF 


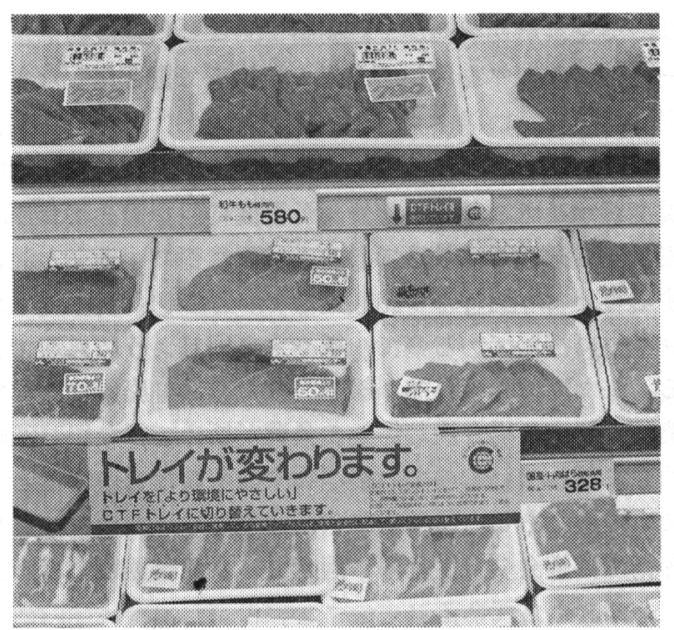

写真 2 灘神戸生協の全店舗に導入された CTFトレー（精肉売り場にて）

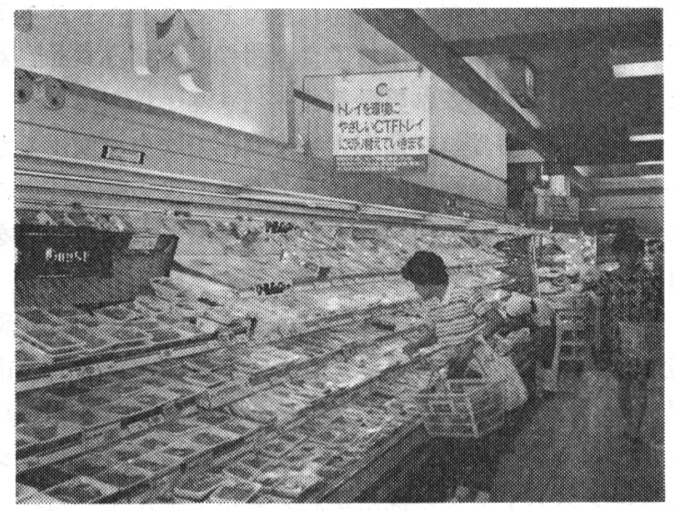

写真 3 灘神戸生協の全店舗に導入された CTFトレー（精肉売り場にて）

設備を設置するなど，CT・CTF の生産体制の増強を積 極的に展開している（写真 2,3 ）。

\section{3-2. A-PET 容器}

PET とは，ポリエチレンテレフタレート樹脂のこと で, パッケージ材料をはじめ電子材料, 衣料材料なと゚各 種の産業用拉よび民生用の材料として幅広く使用されて いる。PET 樹脂の特徴は, (1)強度や光沢に優れている。 (2)耐油性に優れており, 油性食品の容器としても使用で きる。(3)耐熱性に優れている（PET 樹脂の熱変形温度 は $120^{\circ} \mathrm{C}$ である)。(4)食品容器包装材としての安全性が
第 4 表 A-PET の物性比較

\begin{tabular}{|c|c|c|c|c|c|c|c|c|c|c|c|c|c|c|}
\hline \multirow{3}{*}{$\begin{array}{l}\text { シート } \\
\text { 材 料 } \\
\text { 種 類 }\end{array}$} & \multirow{3}{*}{$\begin{array}{l}\text { 透 } \\
\text { 明 } \\
\text { 性 }\end{array}$} & \multirow{3}{*}{$\begin{array}{l}\text { 光 } \\
\text { 沢 }\end{array}$} & \multirow{3}{*}{$\begin{array}{l}\text { 㓮 } \\
\text { 性 }\end{array}$} & \multicolumn{2}{|c|}{ 耐衝擊性 } & \multirow{3}{*}{$\begin{array}{l}\text { 引 } \\
\text { 張 } \\
\text { 强 } \\
\text { 度 }\end{array}$} & \multirow{3}{*}{$\begin{array}{l}\text { E } \\
\text { ン } \\
\text { ジ } \\
\text { 性 }\end{array}$} & \multicolumn{4}{|c|}{ バリア性 } & \multicolumn{3}{|c|}{ 廃裹性 } \\
\hline & & & & 室 & & & & С̆ & 酸 & 水 & 香 & 然召 & 䡴 & 黒 \\
\hline & & & & 温 & 温 & & & 2 & 素 & 分 & $\eta$ & 炾 个 & 肪 & 煙 \\
\hline$A-P E T$ & (1) & (2) & (2) & (6) & 0 & (c) & (0) & 0 & 0 & 0 & (C) & & 無 & 無 \\
\hline PVC & 0 & 0 & () & 0 & 0 & 0 & 0 & (c) & ( ) & 0 & 0 & & 有 & 有 \\
\hline OPS & (0) & 0 & (O) & & $\Delta$ & 0 & $x$ & $\times$ & $\times$ & $\Delta$ & $\Delta$ & & 無 & 有 \\
\hline 透明一PS & 0 & 0 & (0) & $\triangle$ & $\triangle$ & 0 & $x$ & $x$ & $x$ & $\Delta$ & $\Delta$ & & 無 & 有 \\
\hline$P P$ & $\Delta$ & $\triangle$ & $\triangle$ & (1) & $\Delta$ & $\Delta$ & (c) & $x$ & $\times$ & (c) & $x$ & & 無 & 無 \\
\hline
\end{tabular}

確認されている, なと゚の点である(第 4 表)。

PET 樹脂系の容器には, C-PET と A-PET の二つの 材料があるが, 本稿では環境に負荷の少ない易処理性プ ラスチック容器として A-PET を紹介する。

A-PET 容器とは非晶性 (アモルファス) PET 樹脂容 器のことで, 透明性や表面光沢に優れ, かつ耐油性, 耐 薬品性, ガスバリアー性, 保香性などに優れている容器 であるが,ささらに燃焼時の発熱量が少なく, 易処理タイ プのプラスチック容器として注目されている。

ちなみに, A-PET 容器の廃棄処理の面での特性であ る発熱量は, $\mathrm{kg}$ 当たり 5,500 キロカロリーである。

この A-PET 容器が登場した背景には, その機能や特 性から, 今後の簡易食品容器包装用素材としての期待と 環境保全への配虑のためと見られている。

中央化学では, 生分解性プラスチックの開発や, 自社 技術で開発した CT・CTF 等環境に優しい製品に加え て, 新たに今年から A-PET 容器も発売する予定であ り, 環境への負荷の少ないプラスチック容器の実用化こ そ容器メーカーの責務之捕らえて, 今後も新素材開発に 努めて行きたいと考えている。

<中央化学(株)環境対策室 $>$

\section{参考文献}

1）財団法人・バイオインダストリー協会編：「生分 解性プラスチックの海外調査報告書」(1989)

2）財団法人・バイオインダストリー協会編：「生分 解性プラスチックの可能性調查報告書」(1990)

3）日本貿易振與会編：「生分解性プラスチックの海 外調査報告書」（1990）

4） CMC 編：「生分解性プラスチック」(1990) 